\title{
Towards Valorization of Baobab for the Production of Biofuels
}

\author{
Delia Chilabade ${ }^{1}$, Busiswa Ndaba ${ }^{2}$, Sanette Marx ${ }^{1}$, Sanjib Kumar Karmee ${ }^{1,3^{*}}$
}

\begin{abstract}
${ }^{1}$ School of Chemical and Minerals Engineering, North-West University, Potchefstroom Campus, Private Bag X6001, Potchefstroom 2520, SOUTH AFRICA ${ }^{2}$ Agricultural Research Council- Soil, Climate and Water (ARC-SCW), Private Bag X79, Arcadia, Pretoria, 0001, SOUTH AFRICA

${ }^{3}$ Thermo-Chemical Conversion Technology Division, Sardar Patel Renewable Energy Research Institute (SPRERI), Vallabh Vidyanagar, 388120 Anand, Gujarat, INDIA *Corresponding Author: sanjibkarmee@gmail.com
\end{abstract}

Citation: Chilabade, D., Ndaba, B., Marx, S. and Karmee, S. K. (2021). Towards Valorization of Baobab for the Production of Biofuels. European Journal of Sustainable Development Research, 5(3), em0159. https://doi.org/10.21601/ejosdr/10875

\begin{tabular}{|c|c|}
\hline ARTICLE INFO & ABSTRACT \\
\hline Received: 6 Sep. 2020 & Baobab (Adansonia digitata) is a promising bio-resource distributed across Africa. A variety of biofuels such as \\
\hline Accepted: 1 Feb. 2021 & $\begin{array}{l}\text { biodiesel, bioethanol, bio-oil and biogas can be prepared from feedstock derived from baobab. In this vein, } \\
\text { different parts of baobab plant, for instance oil, fruit shells, and seed cakes can be utilized for biofuel synthesis. } \\
\text { In this study, novozyme- } 435 \text { (CAL-B) was used as a biocatalyst for biodiesel production. Oil to biodiesel } \\
\text { conversion of } 91.8 \pm 2.6 \% \text { was obtained within } 6 \mathrm{~h} \text { reaction time at } 50{ }^{\circ} \mathrm{C} \text { when the molar ratio of oil to methanol } \\
\text { was maintained at } 1: 3 \text {. Biocatalysts are non-toxic and biodegradable, therefore sustainable for the process. The } \\
\text { results showed potential use of baobab oil as a feedstock for biodiesel production. }\end{array}$ \\
\hline
\end{tabular}

Keywords: Adansonia digitata, biodiesel, lipase, biorefinery, sustainability

\section{INTRODUCTION}

Demand for energy is increasing worldwide due to fast pace of industrialization and continuous increase in human population (Sarkar et al., 2012). Consequently, more pressure is being exerted on conventional energy sources (International Energy Agency, 2010). There are alarming concerns over energy security due to increasing demand for fossil energy which is a finite resource. Additionally, combustion of fossil fuels emits greenhouse gases which have been reported to contribute to environmental pollution (Zabed et al., 2017). In order to enhance energy security and environmental sustainability, search for alternative energy sources must be accelerated. Along this line, biomass is one of the feasible and promising sources for alternative energy due to its abundance and sustainability (Yang et al., 2016). Biomass can be converted into various solids, liquids, and gaseous biofuels. Furthermore, biofuels contribute for less greenhouse gas emissions as compared to fossil fuels (Ellabban et al., 2014).

Across the world, different countries have shown interest for the development of renewable fuels. Biodiesel, a viable alternative to petroleum diesel, is one of the major biofuels receiving increasing attention in Africa (Rawat et al., 2014). Biodiesel is produced from plant oils, animal fats and grease (Karmee, 2016). Presently, the most promising energy crop for biodiesel production in Africa is Jatropha (Von Maltitz et al., 2009; International Energy Agency, 2010; Walimwipi et al., 2012). The other promising feedstocks are: castor, coconut, palm, sunflower and soybean oils (Von Maltitz et al., 2009; Walimwipi et al., 2012).

To sustain biodiesel production sector in Africa; it is pertinent that scope of feedstock utilization is diversified. Therefore, different feedstocks need to be identified and tested for their biodiesel production potential to reduce overdependence on few resources. Africa is rich in plants with high oil content which have minimal or no commercial applications; hence, these could be utilized for biodiesel production. Some of the oil bearing plant species available on the continent include A. digitata, Croton megalocarpus, Khaya senegalensis, Hura crepitans L., Afzelia africana and Calodendrum capense (Aliyu et al., 2010; Phahladira et al., 2012; Ogbu and Ajiwe, 2016).

\section{Other Potential Biofuels from Baobab Residues}

In addition to biodiesel, other biofuels including bioethanol, biogas and bio-oil can also be prepared from byproducts/waste generated from the baobab plant. Baobab seedcake and fruit shells can be used to produce bio-oil and bioethanol. Bio-oil is a liquid fuel that can be used for heat and electricity generation in boilers, furnaces, turbines and diesel engines. It can also be upgraded to liquid and gaseous transportation fuels. Bio-oil also serves as a feedstock for producing various chemicals such as food flavouring, specialties, resins, agricultural chemicals and fertilizers. Baobab de-oiled seedcake can be utilized for biogas production. 


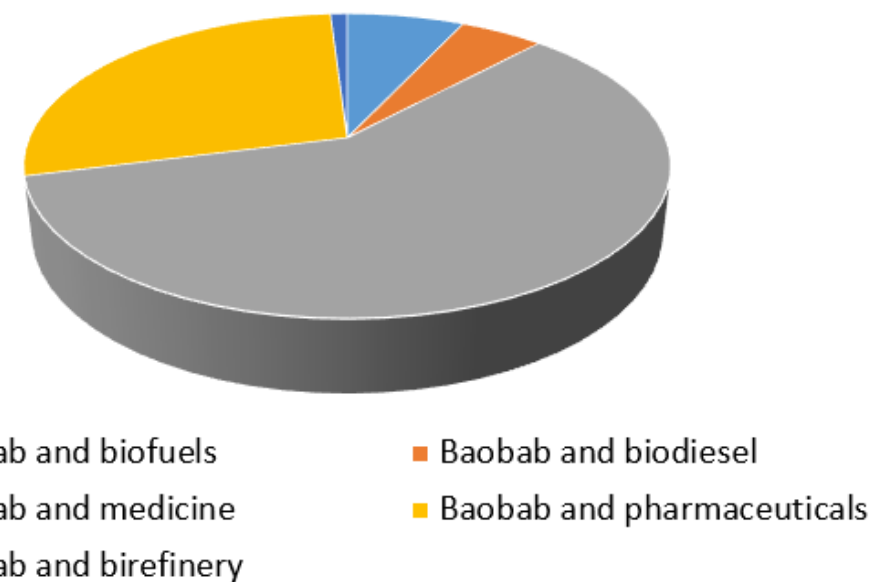

\section{- Baobab and biofuels \\ - Baobab and medicine \\ - Baobab and birefinery}

\author{
Baobab and pharmaceuticals
}

Figure 1. Scientific publications of baobab topics (Source: Science Direct, 2010-2020)

Although baobab has a vast potential to be utilised as a feedstock for biofuels production, such biorefineries are not yet established in Africa (Belyazid et al. 2019). It is reported that sugar content in baobab ranges of $466-877 \mathrm{~g} / \mathrm{kg}$ in baobab samples from Tanzania and South Africa. This shows that it has a great potential for bioethanol production (Parkouda et al. 2012). So far, research on baobab is carried out in lab scale and utilization of baobab as a feedstock for the production of biofuels in pilot scale needs to be carried out. Pilot scale trial experiments to produce biofuels from baobab will attract investment from industries.

A. digitata is a tree belonging to the Malvaceae family and the genus Adansonia (Rahul et al., 2015; Venter et al., 2011). The tree is also known as "monkey bread tree" or "upsidedown tree" or "baobab" in some parts of the world (Sidibe et al., 2002). Baobab grows naturally without cultivation throughout the African continent (Egbadzor, 2020). The fruit of this tree bears a yellowish-white acidic powder usually known as fruit pulp. It is estimated that $1 \mathrm{~kg}$ of fruit can produce nearly 1700-2500 seeds (Sacande et al., 1995). The seed kernels contain golden yellow oil that can be obtained through screw pressing method (Ibrahim, 2016).

Oil yields ranging between $13 \mathrm{wt} \%$ and $45 \mathrm{wt} \%$ have been obtained from baobab seeds by several researchers (Chindo et al., 2010; Donkor et al., 2014; Nkafamiya et al., 2007). The oil is usually extracted via soxhlet extraction method. In a study by Donkor et al. (2014) 13 wt \% oil was obtained through soxhlet extraction with hexane, while extraction using petroleum ether produced approximately $29 \mathrm{wt} \%$ oil. Chindo et al. (2010) obtained oil yield of $33 \mathrm{wt} \%$, while Nkafamiya et al. (2007) obtained $45 \mathrm{wt} \%$. Both studies used petroleum ether as the extracting solvent.

Research has shown that fatty acid composition of the substrate affects the fuel properties of the obtained biodiesel (Lin et al., 2011; Razon, 2009). The composition of fatty acids in the feedstock is a crucial determining factor for a biodiesel producing biomass. Generally, palmitic (C16:0), stearic (C18:0), oleic (C18:1), linoleic (C18:2) and linolenic (C18:3) acids constitute the dominant fatty acids found in traditional biodiesel feedstock, such as, sunflower, rapeseed and soybean oils (Lin et al., 2011). As depicted in Table 1, baobab seed oil is rich in C16:0, C18:0, C18:1, and C18:2 fatty acids. Thus,
Table 1. Fatty acid composition of $A$. digitata oil (Komane et al., 2017; Modiba et al., 2014)

\begin{tabular}{ccc}
\hline Fatty Acid & Content (wt \%) & Content (wt \%) \\
\hline C16:0 & 28.8 & 21 \\
\hline C18:0 & 4.4 & 20.3 \\
\hline C18:1 & 25.1 & 22.1 \\
\hline C18:2 & 36 & 27.5 \\
\hline C18:3 & 0.5 & 8.8 \\
\hline
\end{tabular}

baobab seed oil has potential to serve as a feedstock for biodiesel synthesis.

Although it has been reported that biodiesel can be produced from biomass oils, little is known regarding the potential of the majority of plant seed oils as feedstock for biodiesel production. In this regard, research on baobab is limited and the plant is underutilized even though it is widely distributed across Africa. Figure 2 shows babobab related research publications over a decade. This clearly shows the limited number of publications on the potential use of baobab as substrate for biodiesel production as well its biorefinery approach. Hence, this article presents an overview on utilization of $A$. digitata plant residues as a viable feedstock for biodiesel production and its potential use for a biorefinery.

\section{MATERIALS AND METHODS}

Baobab seed oil was purchased from Nautica Organic Trading Company, Durban, South Africa. The oil was analysed for its fatty acid profile using Gas chromatography (GC) technique.

Experiments carried out in this study involved screening of lipases from different sources and optimization of reaction conditions viz., oil to methanol molar ratio, temperature, and reaction time.

Each experiment commenced with the addition of lipase into a $50 \mathrm{ml}$ pear-shaped reaction flask, followed by addition of oil. To this mixture was then added an appropriate amount of methanol depending on the desired oil to alcohol molar ratio. The reaction vessel was then capped, clamped to a stand, and immersed into a pre-heated oil bath. The transesterification protocol was adopted from Karmee (2016). 


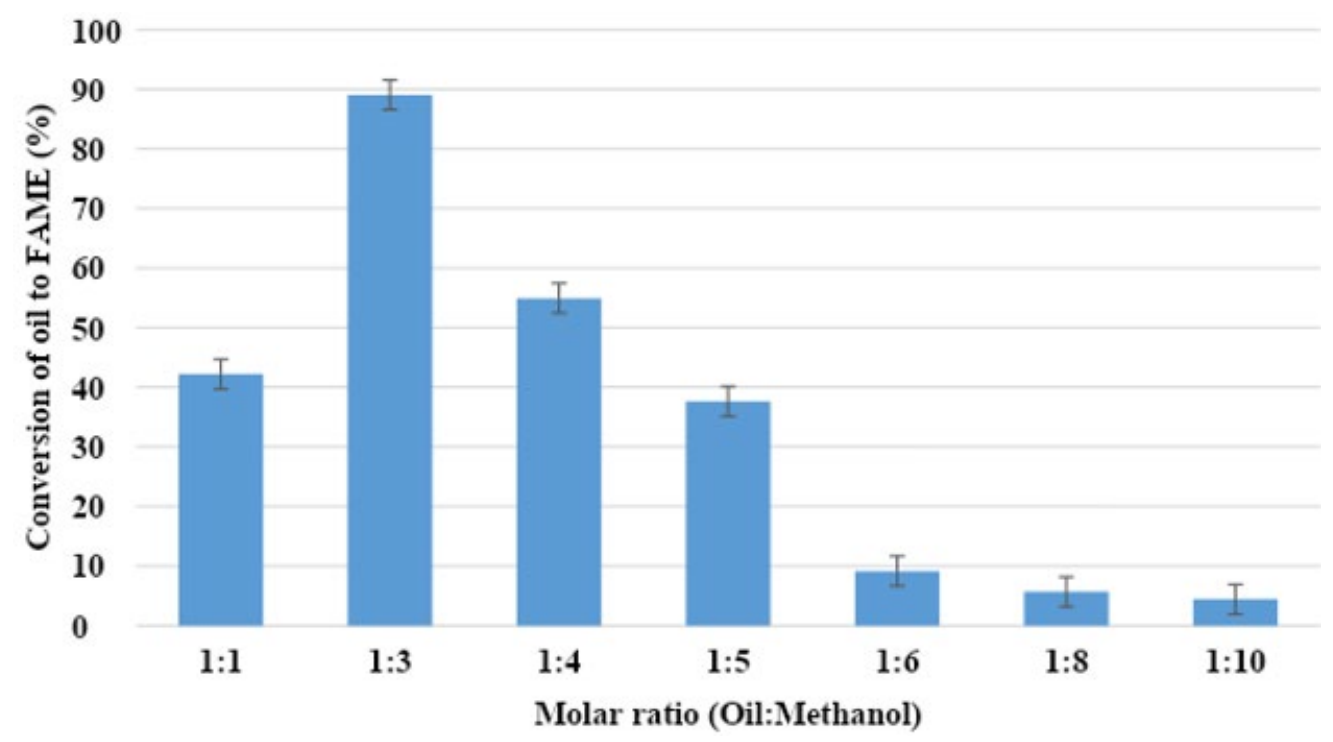

Figure 2. Effect of oil to methanol molar ratio on lipase-catalysed methanolysis of baobab seed oil

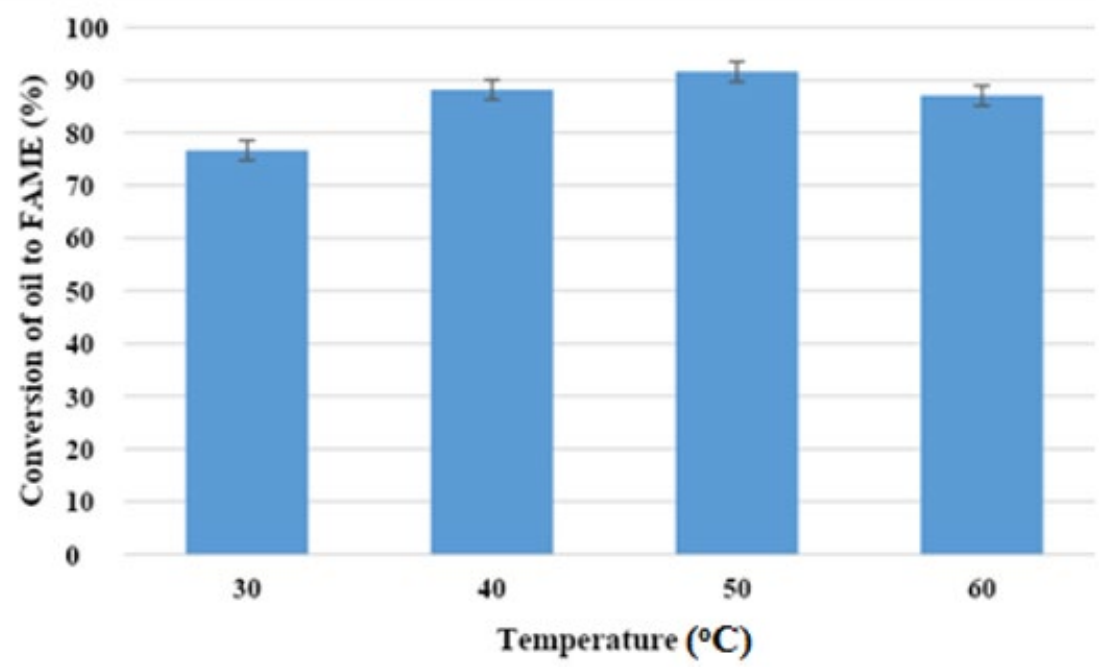

Figure 3. Effect of operating temperature on lipase-catalysed methanolysis of baobab seed oil

Baobab seed oil was analysed using a gas chromatograph equipped with a flame ionization detector (FID) to determine its molecular weight and fatty acid profile. An Agilent 7820A GC system was used for the quantification analysis. The instrument is equipped with a $100 \mathrm{~m} \mathrm{HP}-88$ capillary column and uses helium as carrier gas. Operating conditions used for GC-FID analysis included $1 \mu$ injection volume as well as inlet temperature and pressure of $250^{\circ} \mathrm{C}$. The FID temperature was kept at $350^{\circ} \mathrm{C}$ with detector gas flow of hydrogen $\left(\mathrm{H}_{2}\right)$ : 40 $\mathrm{ml} / \mathrm{min}$; Air: $400 \mathrm{ml} / \mathrm{min}$.

\section{RESULTS AND DISCUSSION}

The feasibility of baobab seed oil as feedstock for biodiesel production has been investigated by Modiba et al. (2014). In this study, baobab seed oil was transesterified with methanol in presence of $\mathrm{NaOH}$ as a homogeneous catalyst to produce biodiesel. At $60{ }^{\circ} \mathrm{C}$, the reaction was optimized using $30 \mathrm{wt} \%$ methanol with respect to oil and 1.4 wt\% catalyst to oil ratio yielded $96 \mathrm{wt} \%$ biodiesel after $1 \mathrm{~h}$ of reaction.
A study by Chilabade (2017) showed that biodiesel production from baobab seed oil via lipase-catalysed transesterification is feasible. The fatty acid profile was used to compute the molecular weight of the oil. The molecular weight of the baobab seed oil used in this study was calculated to be $577.58 \mathrm{~g} / \mathrm{mol}$. For this purpose, several lipases viz. Candida antarctica lipase- $B$, Porcine pancreas, Candida sp., Candida rugosa and Pseudomonas fluorescens, were screened. The results showed Candida antarctica lipase- $B$ as the best catalyst for highest conversion of baobab seed oil to biodiesel. Chilabade also assessed the effects of various reaction conditions including oil to methanol molar ratio, temperature, and time on methanolysis of baobab seed oil catalysed by 10 wt \% Candida antarctica lipase-B and the results are presented in Figures 2-4. A $91.8 \pm 2.6 \%$ conversion of oil to biodiesel could be achieved under optimized conditions of $1: 3$ feedstock to methanol molar ratio, $50^{\circ} \mathrm{C}$, and $6 \mathrm{~h}$ of reaction time. These findings are similar to outcomes from a study by Lamayi et al. (2016). In their study, oil was transesterified using absolute ethanol and $\mathrm{KOH}$ as catalyst. It was observed that optimum conditions yielded $96 \%$ biodiesel. 


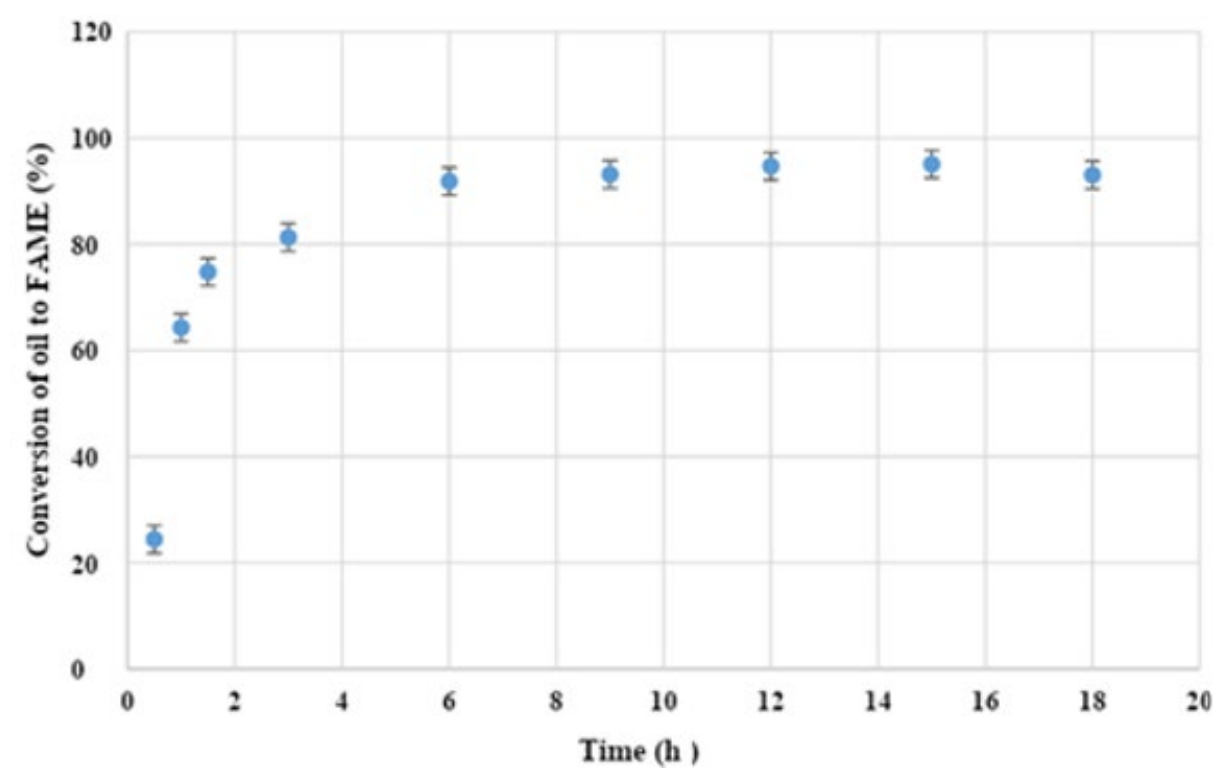

Figure 4. Effect of reaction time on lipase-catalysed transesterification of baobab seed oil

Table 2. Comparison of fuel properties of baobab biodiesel with ASTM D6751-02 and EN 14214 biodiesel specification standards (Modiba et al., 2014)

\begin{tabular}{ccc}
\hline Fuel properties & Baobab & ASTM D6751-02 \\
\hline Kinematic viscosity $\left(\mathrm{mm}^{2} / \mathrm{s}\right)$ & 4.46 & $1.9-6.00$ \\
\hline Density $\left(\mathrm{Kg} / \mathrm{m}^{3}\right)$ & 882 & $860-900$ \\
\hline Flash point $\left({ }^{\circ} \mathrm{C}\right.$ & 192 & $>130$ \\
\hline Pour point $\left({ }^{\circ} \mathrm{C}\right)$ & -1 & $-15-10$ \\
\hline Cloud point $\left({ }^{\circ} \mathrm{C}\right)$ & 2 & $-3-12$ \\
\hline Oxidation stability $(\mathrm{h})$ & 3.09 & $>120$ \\
\hline Cetane number $(\mathrm{min})$ & 57 & - \\
\hline
\end{tabular}

\section{Biodiesel Quality}

Modiba and co-workers compared fuel properties of the biodiesel synthesized from baobab seed oil with ASTM D6751 and EN 14214 biodiesel specifications (Modiba et al., 2014) (Table 2). The tested fuel properties satisfied the specifications except for oxidative stability which did not conform to ASTM D6751 standard. However, oxidation stability of biodiesel fuels can be enhanced by various antioxidant additives which are readily available commercially.

The calorific value of baobab biodiesel was found to be $36.92 \mathrm{MJ} / \mathrm{kg}$. Ultimate analysis indicate the presence of $\mathrm{C}$ (68.6\%), H (10.12\%), and O (26.96\%) in the prepared biodiesel fuel.

\section{Future Prospects of Baobab in Africa}

The sales of co-products, such as seed oil and cake for food and nutrition security have increased economic viability in countries such as Côte d'Ivoire, Kenya and Sudan (Akpata et al., 2013; Ali et al., 2018; Gebauer et al., 2002). These countries also use the pressing method to obtain oil from the seeds, which is exported to cosmetic industries (Europe, United States of America). Baobab has been envisaged to increase biodiesel yield due to its high oil content. However, developing a baobab-based refineries in Africa will require a careful assessment of the supply chain and life-cycle to avoid unforeseen consequences. Production of multiple products from the baobab based biorefinery could increase the economic viability of the complete process and different products obtained from it.

Even though baobab has not been fully explored for biofuel production in Africa, other promising feedstock for biodiesel production in Africa are oil palm and Jatropha, which were proposed in Nigeria; whereas, soybean, sunflower, and canola were proposed as feedstock in several countries including South Africa. Overall, more research as proof-of-concept for baobab as feedstock for biofuel production is required to subsequently apply the laboratory tested concepts for pilot scale production. Pilot scale demonstrations will determine the scaling-up potential and will prove viability of baobab as feedstock.

\section{CONCLUSIONS}

Currently, A. digitata has limited commercial applications. Considering the energy generation crisis in most African countries, $A$. digitata has a potential to be used as feedstock for biofuel production. In the present paper, baobab seed oil was successfully converted to biodiesel in high yield. An optimum oil to biodiesel conversion of $91.8 \pm 2.6 \%$ was obtained with 10 wt \% Candida antarctica lipase-B lipase enzyme catalyst, 1:3 feedstock to methanol molar ratio, at $50^{\circ} \mathrm{C}$ for $6 \mathrm{~h}$ of reaction time. Valorisation of by-products and waste materials derived from the baobab plant could also generate other important biofuels including bioethanol, biogas, and bio-oil. These 
findings could pave future research for wide adoption of baobab as a feedstock for biodiesel production.

Author contributions: All co-authors have involved in all stages of this study while preparing the final version. They all agree with the results and conclusions.

Funding: The authors are grateful to the North-West University for financial support.

Declaration of interest: There is no potential conflict of interest by authors.

Ethics approval and consent to participate: Not applicable. Availability of data and materials: All data generated or analyzed during this study are available for sharing when appropriate request is directed to corresponding author.

\section{REFERENCES}

Akpata, U., Bredenhann, C. and White, D. (2013). From promise to performance. Africa oil \& gas review. South Africa: PWC. Available at: https://www.pwc.com/ng/en/pdf/pwc-africaoil-and-gas-review.pdf

Ali, A. A. M., Mustafa, M. A. and Yassin, K. E. E. (2018). Production of Bio-oil through Fast Pyrolysis of Baobab Waste Shells. European Journal of Engineering Research and Science, 3(7), 33-37. https://doi.org/10.24018/ ejers.2018.3.7.820

Aliyu, B., Agnew, B. and Douglas, S. (2010). Croton megalocarpus (Musine) seeds as a potential source of biodiesel. Biomass and Bioenergy, 34(10), 1495-1499. https://doi.org/10.1016/j.biombioe.2010.04.026

Balan, V., Rogers, C. A., Chundawat, S. P., da Costa Sousa, L., Slininger, P. J., Gupta, R. and Dale, B. E. (2009). Conversion of extracted oil cake fibers into bioethanol including DDGS, canola, sunflower, sesame, soy, and peanut for integrated biodiesel processing. Journal of the American Oil Chemists' Society, 86(2),157-165. https://doi.org/10.1007/s11746008-1329-4

Belyazid, R. and Mechad, A. (2019). Biofuel: What future for Africa. 39th International Scientific Conference on Economic and Social Development - "Sustainability from an Economic and Social Perspective”- Lisbon, 29-30 April 2019.

Chilabade, D. (2017). Biodiesel production from plant oils of African origin (MSc Thesis). North-West University, Potchefstroom.

Chindo, I., Gushit, J., Olotu, P., Mugana, J. and Takbal, D. (2010). Comparism of the quality parameters of the seed and condiment oil of Adansonia digitata. Journal of American Science, 6(12), 990-994.

Donkor, A. M., Tei, M., Suurbaar, J., Yakubu, A. and Addae, D. (2014). Stability Evaluation and Degradation Kinetics of Ascorbic Acid in Baobab Fruit Pulp Formulated with the Seed Oil. British Biotechnology Journal, 4(5), 566. https://doi.org/10.9734/BBJ/2014/9837

Egbadzor, K. F. (2020). Studies on baobab diversity, seed germination and early growth. South African Journal of Botany, 133,178-183. https://doi.org/10.1016/j.sajb.2020. 07.024
Ellabban, O., Abu-Rub, H. and Blaabjerg, F. (2014). Renewable energy resources: Current status, future prospects and their enabling technology. Renewable and Sustainable Energy Reviews, 39, 748-764. https://doi.org/10.1016/ j.rser.2014.07.113

Gebauer, J., El-Siddig, K. and Ebert, G. (2002). Baobab (Adansonia digitata L.): A Review on a Multipurpose Tree with Promising Future in the Sudan. Horticulture Science, 67(4), 155-160.

Ibrahim, A. M. A. (2016). Extraction of Oils from the seeds of Baobab (Ophelussitularius) and Balanites (Aegilopsgeniculata) (Doctoral dissertation), University of Khartoum.

IEA (International Energy Agency). (2010). World Energy Balances - Excerpt Key World Energy Trends.

IRENA (2016). Bioethanol in Africa: The case for technology transfer and South-South co-operation. International Renewable Energy Agency, Abu Dhabi. Available at: https://www.irena.org/-/media/Files/IRENA/Agency/ Publication/2016/IRENA_Bioethanol_in_Africa_2016.pdf

Karmee, S. K. (2016). Preparation of biodiesel from nonedible oils using a mixture of used lipases. Energy Sources Part A, 38(18), 2727-2733. https://doi.org/10.1080/15567036. 2015.1098748

Komane, B. M., Vermaak, I., Kamatou, G. P. P., Summers, B. and Viljoen, A. M. (2017). Beauty in Baobab: a pilot study of the safety and efficacy of Adansonia digitata seed oil. Revista Brasileira de Farmacognosia, 27(1), 1-8. https://doi.org/10.1016/j.bjp.2016.07.001

Lamayi, D. W., Jauro, A. and Malgwi, A. H. (2016). Production and optimization of ethyl ester produced from Adansonia digitata seed oil. Journal of Applied Chemical Science International, 6(4), 186-194.

Lin, L., Cunshan, Z., Vittayapadung, S., Xiangqian, S. and Mingdong, D. (2011). Opportunities and challenges for biodiesel fuel. Applied Energy, 88(4), 1020-1031. https://doi.org/10.1016/j.apenergy.2010.09.029

Lynd, L. R., Von Blottnitz, H., Tait, B., De Boer, J., Pretorius, I. S., Rumbold, K. and Van Zyl, W. H. (2003). Plant Biomass Conversion to Fuels and Commodity Chemicals in South Africa: A Third Chapter. South African Journal of Science, 99, 499-507.

Mitchell, D. (2010). Biofuels in Africa: opportunities, prospects, and challenges. The World Bank. https://doi.org/10.1596/978-0-8213-8516-6

Modiba, E., Osifo, P. and Rutto, H. (2014). Biodiesel production from baobab (Adansonia digitata L.) seed kernel oil and its fuel properties. Industrial Crops and Products, 59, 50-54. https://doi.org/10.1016/j.indcrop.2014.04.044

Mohanty, S. K. and Swain, M. R. (2019). Bioethanol Production from Corn and Wheat: Food, Fuel, and Future. In Bioethanol Production from Food Crop. 45-59. Academic Press. $\quad$ https://doi.org/10.1016/B978-0-12-8137666.00003-5 
Mohit, S. M., Chandrashekhar, B., Tanushree, C. and Kanwal, S. (2011). Production of bio-ethanol from Jatropha oilseed cakes via dilute acid hydrolysis and fermentation by Saccharomyces cerevisiae. International Journal of Applied Sciences and Biotechnology, 3, 41-47. https://doi.org/10.9735/0975-2943.3.1.41-47

Muktham, R., Ball, A. S., Bhargava, S. K. and Bankupalli, S. (2016). Bioethanol production from non-edible de-oiled Pongamia pinnata seed residue-optimization of acid hydrolysis followed by fermentation. Industrial Crops and Products, 94, 490-497. https://doi.org/10.1016/j.indcrop. 2016.09.019

Nkafamiya, I., Osemeahon, S., Dahiru, D. and Umaru, H. (2007). Studies on the chemical composition and physicochemical properties of the seeds of baobab (Adasonia digitata). African Journal of Biotechnology, 6(6), 756-759.

Nwufo, O., Nwafor, O. and Igbokwe, J. (2016). Effects of blends on the physical properties of bioethanol produced from selected Nigerian crops. International Journal of Ambient Energy, 37(1), 10-15. https://doi.org/10.1080/01430750. 2013.866907

Ogbu, I. and Ajiwe, V. (2016). FTIR studies of thermal stability of the oils and methyl esters from Afzelia africana and Hura crepitans seeds. Renewable Energy, 96, 203-208. https://doi.org/10.1016/j.renene.2016.04.055

Parkouda, C., Sanou, H., Tougiani, A., Korbo, A., Nielsen, D. S., Tano-Debrah, K., Ræbild, A., Diawara, B. \& Jensen, J. S. (2012). Variability of Baobab (Adansonia digitata L.) fruits' physical characteristics and nutrient content in the West African Sahel. Agroforestry systems, 85(3), 455-463. https://doi.org/10.1007/s10457-011-9406-3

Phahladira, M. N. B., Viljoen, R. and Pietersen, G. (2012). Widespread occurrence of "Candidatus liberibacter africanus subspecies capensis" in Calodendrum capense in South Africa. European Journal of Plant Pathology, 134(1), 39-47. https://doi.org/10.1007/s10658-012-0020-7

Rahul, J., Jain, M. K., Singh, S. P., Kamal, R. K., Naz, A., Gupta, A. K. and Mrityunjay, S. K. (2015). Adansonia digitata L.(baobab): a review of traditional information and taxonomic description. Asian Pacific Journal of Tropical Biomedicine, 5(1), 79-84. https://doi.org/10.1016/S22211691(15)30174-X

Rawat, D. S., Joshi, G., Lamba, B. Y., Tiwari, A. K. and Mallick. S. (2014). Impact of additives on storage stability of Karanja (Pongamia Pinnata) biodiesel blends with conventional diesel sold at retail outlets. Fuel, 120, 30-37. https://doi.org/10.1016/j.fuel.2013.12.010
Razon, L. F. (2009). Alternative crops for biodiesel feedstock. $C A B$ Reviews: Perspectives in agriculture, veterinary science, nutrition and natural resources, 4(56), 1-15. https://doi.org/10.1079/PAVSNNR20094056

Sacande, M., Rønne, C., Sanon, M. and Jøker, D. (2006). Adansonia digitata L. Forest and Landscape Denmark. Seed Leaflet, 87, 1-2. https://sl.ku.dk/rapporter/seedleaflets/filer/calophyllum-87-int.pdf

Sánchez, Ó. J. and Cardona, C. A. (2008). Trends in biotechnological production of fuel ethanol from different feedstocks. Bioresource Technology, 99(13), 5270-5295. https://doi.org/10.1016/j.biortech.2007.11.013

Sarkar, N., Ghosh, S. K., Bannerjee, S. and Aikat, K. (2012). Bioethanol production from agricultural wastes: An overview. Renewable Energy, 37(1), 19-27 https://doi.org/10.1016/j.renene.2011.06.045

Sidibe, M., Williams, J. T. (2002). Baobab, Adansonia Digitata L. Edited by A. Hughes, N. Haq and R. Smith. Fruits for the Future 4.

Stafford, W. H. L., Lotter, G. A., von Maltitz, G. P. and Brent, A. C. (2019). Biofuels technology development in Southern Africa. Development Southern Africa, 36(2), 155-174. https://doi.org/10.1080/0376835X.2018.1481732

Venter, S. M. and Witkowski, E. T. F. (2011). Baobab (Adansonia digitata L.) fruit production in communal and conservation land-use types in Southern Africa. Forest Ecology and Management, 261(3), 630-639. https://doi.org/10.1016/j.foreco.2010.11.017

Von Maltitz, G., Haywood, L., Mapako, M. and Brent, A. (2009). Analysis of opportunities for biofuel production in subSaharan Africa. CIFOR.

Walimwipi, H., Yamba, F. D., Wörgetter, M., Rathbauer, J. and Bacovsky, D. (2012). Biodiesel Production in Africa. In R. Janssen and D. Rutz (Eds.), Bioenergy for Sustainable Development in Africa (pp. 93-102). Dordrecht: Springer Netherlands. https://doi.org/10.1007/978-94-007-21814_9

Yang, L., Nazari, L., Yuan, Z., Corscadden, K., Xu, C. and He, Q. (2016). Hydrothermal liquefaction of spent coffee grounds in water medium for bio-oil production. Biomass and Bioenergy, 86,191-198. https://doi.org/10.1016/j.biombioe. 2016.02.005

Zabed, H., Sahu, J., Suely, A., Boyce, A. and Faruq, G. (2017). Bioethanol production from renewable sources: Current perspectives and technological progress. Renewable and Sustainable Energy Reviews, 71, 475-501. https://doi.org/10.1016/j.rser.2016.12.076 